\title{
薬 物
}

\section{新 Cephem 系抗生物質 Cefmenoxime の試験} 管内抗菌力,水溶液の安定性および化膿性中耳炎 に対する局所的応用に関する検討

岩沢武彦

\begin{abstract}
A Study of in Vitro Antibacterial Activity, Stability of Solution and Local Application Against Purulent Otitis Media of a New Cephem Derivative Antibiotic, Cefmenoxime
\end{abstract}

\section{Takehiko Iwasawa}

(Sapporo Teishin Hospital)

The antibacterial activity, stability of solution and clinical efficacy of a new cephem derivative antibiotic, Cefmenoxime, were studied with results which led to the following conclusions:

1) In vitro antibacterial activity: The minimum inhibitory concentration of Cefmenoxime was tested by the agar plate dilution method. Cefmenoxime produced an excellent, broad spectrum antibacterial activity against standard strains of various bacteria. Cefmenoxime had the same antibacterial spectrum as those of other cephalosporin antibiotics. The MIC of Staphylococcus aureus isolated from otorrhoea was distributed at a range from 0.39 to $6.25 \mu \mathrm{g} / \mathrm{ml}$ of Cefmenoxime, showing its peak at $1.56 \mu \mathrm{g} / \mathrm{ml}$. Other strains, Escherichia coli, Proteus mirabilis and Klebsiella pneumoniae were inhibited by $\leqq 0.2$ to $0.78 \mu \mathrm{g} / \mathrm{ml}$ with its peak at $\leqq 0.2 \mu \mathrm{g} / \mathrm{ml}$ of Cefmenoxime. Cefmenoxime showed the MICs of 6.25 to $50 \mu \mathrm{g} / \mathrm{ml}$ with its peak at $12.5 \mu \mathrm{g} / \mathrm{ml}$ against 60 strains of pathogenic Pseudomonas aeruginosa.

2) Stability of Cefmenoxime solution: Twenty $\mathrm{mg} / \mathrm{ml}$ of Cefmenoxime stable with no change in color, $\mathrm{pH}$ or antibacterial activity when the solution was kept at $5^{\circ} \mathrm{C}$ or $37^{\circ} \mathrm{C}$ for 12 days.

3) Results of clinical treatment: When Cefmenoxime was applied locally in 33 
cases of acute and chronic purulent otitis, results were good in 22, fair in 5 and poor in 6 cases. When good and fair effects were considered together, the rate of effectiveness was 27 cases or 81.8 per cent.

No side effect was observed when Cefmenoxime $20 \mathrm{mg} / \mathrm{ml}$ solution was locally applied.

\section{緒言}

近仲，急性化膿性:川耳炎の耳湅分離菌は，通常，人部分が Staphylococcus, aureus, Streptococcus pyogenes および Streptococcus pneumoniae よ゙のグラム陽性球菌や Haemophilus influenzae などで!わられている。慢性:化膿性:川耳炎の分離莉は，いぜん多剂耐性の Staphylococcus aureus が主体であるが, Pseudomonas aeruginosa, Proteus, Serratia などのグラム除 性:棹菌や Pseudomonas aeruginosa 以外のブドウ糖非醗酵グラム陰性菌, 嫌気性: 菌あるいは真莉 などが単独もしくは混合（䘳合）感染として検出される埸合が多い.

$\beta$-lactam 系抗生物質の研究開発は，とりわけ，cephalosporin 系扰よび cephamycin 系抗生物 質の合成の進步発辩が著しく，グラム除性桿菌に対して抗菌スペクトルが拡大され，さらに $\beta$ lactamase に安定性の高い抗生物質が相ついで登埸してきた。

新抗生物質 Cefmenoxime(CMX) は, 武田诌品中央研焱所で, 従米の cephalosporin 系抗生物 質よりグラム陰性棹菌や嫌気性菌に抗菌力がすぐれ，かつ $\beta$-lactamase に対して強い抵抗性を示 し，既知 cepalosporin 耐性菌に対しても強い抗莉活性を有する国産の半合成 cephalosporin 系抗 生物質である.

新 cephalosporin 系抗生物質 Cefmenoxime の物理化学的性状は, 日色ないし带橙黄色の結晶 または結晶性の粉木であり, ジメチルスルホキシドに易溶, メタノールに政めて難溶, 水, エタノ 一ルまたはアセトンにはほとんど不溶である. Cefmenoxime の化学構造式は, Fig.1に示したよ おり，7位側鎖に aminothiazolyl-methoxyiminoacetyl 基を有し，また 3 位側鎖に tetrazole 環 を有している. Cefmenoxime の分子式は, $\mathrm{C}_{16} \mathrm{H}_{17} \mathrm{~N}_{9} \mathrm{O}_{5} \mathrm{~S}_{3} 1 / 2 \mathrm{HCl}$ で表示され, 分千量は529.78 算定されている. Cefmenoxime の㚣全性は，動物実験で急性，亚急性および慢性瑇性試験で病変 なく，また胎仔奇形作用屯認められないという”。

著者は，新抗生物質 Cefmenoximeについて試験管内抗菌力，水溶液の安定性および化膿性中耳 炎に対して局所的に応用した結果, 良好な成績がえられたので報告する。<smiles>CO/N=C(\C(=O)NC1C(=O)N2C(C(=O)O)=C(CSc3nnnn3C)CSC12)c1csc(N)n1</smiles>

Fig. 1 Chemical structure of Cefmenoxime

\section{試験管内抗菌力}

標準菌㧍よび病巣分離藏に対する Cefmenoxime を含わた齐抗牛物所の試験管内抗莉力 は，つぎのと扔りの実験うj法にしたがい冬被榆 菌株に対する抗菌力を調べた。 
1) 実験方法 : 各被検菌株に対する Cefmenoxime を含めた各薬剂の試験管内抗菌力は, 日本化学療法学会M I C小委員会の指示基準に したがい，寒天平板希釈法で各被検薬剤の細菌 に対する最小発育阻止濃度 Minimum inhbitory concentration (MIC) を測定した.

Cefmenoxime の抗菌力試験の比較抗生物質 は, Cephalexin (CEX), Cephradine (CED), Cephaloglycin (CEG), Cephalothin (CET), Cephaloridine (CER), Cefazolin (CEZ), Cephapirin (CEPR), Ceftezole (CTZ), Cephacetrile (CEC), Cefoperazone (CPZ), Cefotiam(CTM) および Latamoxef(LMOX) などの12種類の cephalosporin 系抗生物質と Penicillin G (PCG), Aminobenzylpenicillin (ABPC), Carboxybenzylpenicillin (CBPC), Aminocyclohexylpenicillin (ACPC), Streptomycin (SM), Kanamycin (KM), Aminodioxykanamycin (AKM), Ribostamycin (RS M), Gentamicin (GM), Lividomycin (LVD $\mathrm{M})$, Erythromycin (EM), Oleandomycin (O $\mathrm{M})$, Leucomycin (LM), Spiramycin (SPM), Josamycin (JM), Lincomycin (LCM), Tetracycline (TC), Chloramphenicol $(\mathrm{CP})$, Poly- mixin B (PLB) および Colistin (CL) など24 種既知抗生物質についてそれぞれM I Cを測定 し, Cefmenoxime と抗菌力を比較検討した。

抗菌力試験の被検菌株は, 各研究機関から分 与を受けた標準菌26株と化膿性中耳炎の耳漏か ら分離同定した coagulase 陽性ブドウ球菌80 株と病巣から分離たし Escherichia coli 25株, Proteus mirabilis 24株, Klebsiella pneumoniae 20株掞よび Peudomonas aeruginosa 60 株を抗菌力試験の対象菌株とした。

抗菌力試験用培地は, Heart infusion agar (栄研)を使用し, 接種菌は Trypto-soy broth で $37^{\circ} \mathrm{C}$ の餒卵器内で 18 時間増菌培養を行ない, グラム陽性菌は $10^{6} \mathrm{cells} / \mathrm{ml}$, グラム陰性菌で は $10^{8} \mathrm{cells} / \mathrm{ml}$ を前記の試験培地に画線塗抹 し, $37^{\circ} \mathrm{C}, 24$ 時間培養後, 培地上に発生した菌 集落の有無を肉眼的観察により各被検薬剤の $\mathrm{M}$ I Cを測定した最高希釈濃度を $100 \mu \mathrm{g} / \mathrm{ml}$ と し，その薬剤の最低希釈濃度を $0.2 \mu \mathrm{g} / \mathrm{ml}$ と した各被検薬剤の希釈系列を作製した。

2 ）実験成績：標準菌株に対する Cefmenoxime の抗菌力試験の成績は, Table 1 に示し たとおり, Cefmenoxime はグラム陽性球菌の Staphylococcus aureus は $0.78 \sim 1.56 \mu \mathrm{g} / \mathrm{ml}$

Table 1 Comparison of antibacterial spectrum of cephems

A) Gram-positive bacteria $\left(10^{6}\right.$ cells $\left./ \mathrm{ml}\right) \mathrm{MIC}(\mu \mathrm{g} / \mathrm{ml})$

\begin{tabular}{l|l|l|l|l}
\hline Test organisms & CMX & CPZ & CEC & CTZ \\
\hline S. aureus 209 P JC-1 & 0.78 & 0.78 & 0.39 & 0.1 \\
S. aureus TERAJIMA & 1.56 & 1.56 & 0.78 & 0.39 \\
S. aureus NEUMANN & 1.56 & 1.56 & 0.78 & 0.39 \\
S. aureus SMITH & 1.56 & 1.56 & 0.39 & 0.2 \\
S. pyogenes DENKEN & 0.1 & 0.1 & 0.39 & 0.2 \\
S. pyogenes COOK & 0.1 & 0.2 & 0.78 & 0.39 \\
S. pyogenes DICK & 0.1 & 0.1 & 0.39 & 0.2 \\
S. pneumoiae Type III & 0.1 & 0.1 & 0.2 & 0.39 \\
B. subtilis PCI 219 & 1.56 & 0.39 & 0.2 & 0.1 \\
B. subtilis ATCC 6633 & 0.78 & 0.39 & 0.1 & 0.1 \\
M. luteus PCI 1001 & 0.1 & 0.39 & 0.39 & 0.39 \\
C. diphtheriae PW 8 & 0.39 & 1.56 & 0.78 & 0.78
\end{tabular}


Table 2 Comparison of antibacterial spectrum of cephems

B) Gram-negative bacteria $\left(10^{\circ}\right.$ cells $\left./ \mathrm{ml}\right)$ MIC $(\mu \mathrm{g} / \mathrm{ml})$

\begin{tabular}{l|c|c|c|c}
\hline \multicolumn{1}{|c|}{ Test organisms } & CMX & CPZ & CEC & CTZ \\
\hline E. coli NIH JC-2 & 0.2 & 0.39 & 25 & 6.25 \\
E. coli IAM 1253 & 0.1 & 0.2 & 12.5 & 3.13 \\
P. vulgaris OX-19 & 0.1 & 0.2 & 6.25 & 100 \\
P. vulgaris ATCC 21100 & 0.1 & 0.2 & 25 & 100 \\
P. mirabilis PR-4 & 0.1 & 0.2 & 12.5 & 12.5 \\
K. pneumoniae Type 22 & 0.1 & 0.1 & 12.5 & 3.13 \\
K. pneumoniae 602 & 0.1 & 0.1 & 12.5 & 6.25 \\
P. aeruginosa X-39 & 25 & 3.13 & $>100$ & $>100$ \\
P. aeru inosa DENKEN & 12.5 & 3.13 & $>100$ & $>100$ \\
P. aeruginosa NCTC 10490 & 12.5 & 3.13 & $>100$ & $>100$ \\
P. aeruginosa IAM 11027 & 25 & 3.13 & $>100$ & $>100$ \\
S. typhi T-287 & $<0.1$ & 0.2 & 12.5 & 50 \\
S.flexneri 2a & $<0.1$ & $<0.1$ & 12.5 & 1.56 \\
& & & &
\end{tabular}

Table 3 Comparison of antibacterial activity of Cefmenoxime with that of cephalosporins against 80 coagulase positive staphylococcal strains

\begin{tabular}{|c|c|c|c|c|c|c|c|c|c|c|}
\hline \multirow{2}{*}{ Drugs } & \multicolumn{10}{|c|}{ Minimum inhibitory concentration $(\mu \mathrm{g} / \mathrm{ml})$} \\
\hline & $\leqq 0.2$ & 0.39 & 0.78 & 1.56 & 3.13 & 6.25 & 12.5 & 25 & 50 & $\geqq 100$ \\
\hline $\mathrm{CMX}$ & & 13 & 18 & 38 & 9 & 2 & & & & \\
\hline $\mathrm{CEZ}$ & 4 & 17 & 15 & 14 & 11 & 12 & & 5 & 2 & \\
\hline CEG & 1 & 4 & 2 & 5 & 19 & 31 & 12 & 4 & & 2 \\
\hline CED & 3 & 9 & 5 & 2 & 7 & 22 & 17 & 7 & 4 & 4 \\
\hline CEX & 3 & 3 & 4 & 12 & 17 & 25 & 11 & & & 5 \\
\hline CEPR & 51 & 11 & 11 & 3 & & 1 & 1 & & & 2 \\
\hline CET & 44 & 18 & 10 & 1 & 1 & 3 & & & & 3 \\
\hline CER & 40 & 8 & 9 & 5 & 2 & 8 & 1 & 2 & 1 & 4 \\
\hline CTZ & 19 & 23 & 16 & 9 & 5 & 3 & 2 & 1 & 2 & \\
\hline CEC & & 9 & 34 & 22 & 10 & 3 & 2 & & & \\
\hline $\mathrm{CPZ}$ & 2 & 1 & 10 & 29 & 23 & 8 & 4 & 2 & 1 & \\
\hline СТM & 4 & 31 & 22 & 13 & 8 & 2 & & & & \\
\hline LMOX & & & & & 2 & 34 & 29 & 8 & 4 & 3 \\
\hline
\end{tabular}

のM I Cであり, Streptococcus pyogenes および Streptococcus pneumoiae は $<0.1 \mu \mathrm{g}$ /ml のM I Cを示した。また, Bacillus sub- tilisは $0.78 \sim 1.56 \mu \mathrm{g} / \mathrm{ml}$ の M I Cであり, M.luteus は $<0.1 \mu \mathrm{g} / \mathrm{ml}$, Corynebacterium diptheriae は $0.39 \mu \mathrm{g} / \mathrm{ml}$ の I Cを示し, 他 
Table 4 Comparison of antibacterial activity of Cefmenoxime with that of other antibiotics against 80 coagulase positive staphylococcal strains

\begin{tabular}{|c|c|c|c|c|c|c|c|c|c|c|}
\hline \multirow{2}{*}{ Drugs } & \multicolumn{10}{|c|}{ Minimum inhibitory concentration $(\mu \mathrm{g} / \mathrm{ml})$} \\
\hline & $\leqq 0.2$ & 0.39 & 0.78 & 1.56 & 3.13 & 6.25 & 12.5 & 25 & 50 & $\geqq 100$ \\
\hline $\mathrm{CMX}$ & & 13 & 18 & 38 & 9 & 2 & & & & \\
\hline PCG & 11 & 6 & 5 & 5 & 8 & 10 & 2 & 9 & 10 & 14 \\
\hline $\mathrm{ABPC}$ & 7 & 5 & 8 & 9 & 12 & 8 & 7 & 12 & 7 & 5 \\
\hline SM & 3 & 1 & 5 & 7 & 17 & 3 & 1 & 2 & & 41 \\
\hline $\mathrm{KM}$ & 3 & 2 & 4 & 20 & 13 & 11 & 1 & 2 & & 24 \\
\hline AKM & 9 & 7 & 8 & 21 & 17 & 1 & 1 & 1 & 1 & 14 \\
\hline GM & 38 & 11 & 17 & 2 & 5 & 2 & 3 & 1 & & 1 \\
\hline $\mathrm{EM}$ & 21 & 3 & 6 & 1 & 1 & & 1 & & 2 & 45 \\
\hline OL & 5 & 4 & 13 & 8 & 4 & 2 & 2 & 8 & 5 & 29 \\
\hline LM & 1 & & 4 & 29 & 13 & 1 & & & 1 & 31 \\
\hline SPM & & & & & 9 & 22 & 8 & 3 & 2 & 36 \\
\hline $\mathrm{JM}$ & 5 & 2 & 8 & 19 & 17 & & 2 & 8 & 6 & 13 \\
\hline LCM & 4 & 3 & 15 & 17 & 3 & 4 & 2 & 1 & 1 & 30 \\
\hline TC & 3 & 9 & 4 & 6 & 3 & 3 & 5 & 1 & & 46 \\
\hline $\mathrm{CP}$ & & & & & 3 & 8 & 27 & 8 & 9 & 25 \\
\hline
\end{tabular}

の比較したC P Z ，C E C，C T Z および LM OX などの cephalosporin 系抗生物質より数 段階抗菌力がすぐれていた.グラム陰性菌に対 する Cefmenoxime の抗菌力は, Table 2 に示 したとおり, Escherichia coli に $0.1 \sim 0.2 \mu \mathrm{g}$ $/ \mathrm{ml}$, Proteus vulgaris. mirabilis $に は<0.1 \mu \mathrm{g}$ $/ \mathrm{ml}$, Klebsiella pneumoniae $飞 0.1 \mu \mathrm{g} / \mathrm{ml}$ の低いM I Cで菌の発育を阻止した。なお, Cefmenoxime は, Pseudomonas aeruginosa には $12.5 \sim 25 \mu \mathrm{g} / \mathrm{ml}$ と高い M I C を示し, Salmonella thyphi, Shigella flexneri には $<0.1 \mu \mathrm{g} / \mathrm{ml}$ の低いM I Cであった.

化膿性中耳炎の耳漏から分離同定した coagulase 陽性ブドウ球菌80株に対する Cefmenoxime の抗菌力は, Table 3 に示したとおり, $0.39 \sim 6.25 \mu \mathrm{g} / \mathrm{ml}$ の範囲内に感受性が分布し ており, とりわけ $0.78 \sim 3.13 \mu \mathrm{g} / \mathrm{ml}$ にM I C が集中化し, $1.56 \mu \mathrm{g} / \mathrm{ml}$ にM I Cの peak が
認められた。なお， $12.5 \mu \mathrm{g} / \mathrm{ml}$ 以上の高度耐 性株はみられなかった. Cefmenoximeは，他 のCET，CER，CTZおよび CEPR など の cephalosporin 系抗生物質の注射剂之比較 するとやや抗菌力は弱かったが，その他の cephalosporin 系抗生物質之同等むしくは抗菌力 が優っていた。 また, Cefmenoxime と cephalosporin 系以外の他既知抗生物質との比較 では，Table 4 に示したとおり，Cefmenoxime と同等もしくは抗菌力がすぐれていた。

病巣分離の Escherichia coli 25株に対する Cefmenoxime の抗菌力は, Table 5 に示した と抢り， $\leqq 0.2 \sim 0.78 \mu \mathrm{g} / \mathrm{ml}$ 飞感受性が分布 し, $\leqq 0.2 \mu \mathrm{g} / \mathrm{ml}$ にM I Cの peak がみられ， 他の比較抗生物質より抗菌力が極めて強かっ た.

病巣分離の Proteus mirabilis 24株に対する Cefmenoxime の抗菌力は, Table 6 に示した 
Table 5 Comparison of antibacterial activity of Cefmenoxime with that of other antibiotics against E.coli

\begin{tabular}{|c|c|c|c|c|c|c|c|c|c|c|c|}
\hline \multirow{2}{*}{ Drugs } & \multirow{2}{*}{$\begin{array}{l}\text { No. of } \\
\text { strains }\end{array}$} & \multicolumn{10}{|c|}{ Minimum inhibitory concentration $(\mu \mathrm{g} / \mathrm{ml})$} \\
\hline & & $\leqq 0.2$ & 0.39 & 0.78 & 1.56 & 3.13 & 6.25 & 12.5 & 25 & 50 & $\geq 100$ \\
\hline $\mathrm{CMX}$ & 25 & 21 & 3 & 1 & & & & & & & \\
\hline ABPC & 46 & & & & 8 & 2 & 8 & 9 & 5 & & 14 \\
\hline $\mathrm{CBPC}$ & 46 & & & 2 & & 2 & 6 & 9 & 4 & 14 & 9 \\
\hline ACPC & 14 & & & & & & & & & 2 & 12 \\
\hline SBPC & 26 & & & & & 3 & 5 & 5 & 6 & 4 & 3 \\
\hline AKM & 7 & & & 1 & 4 & & 1 & & & & 1 \\
\hline RSM & 36 & & & & & & 11 & 13 & 8 & & 4 \\
\hline GM & 43 & & 9 & 15 & 14 & 5 & & & & & \\
\hline LVDM & 47 & & & & 4 & 7 & 20 & 7 & 7 & & 2 \\
\hline CEX & 14 & & & & 1 & & & 6 & 6 & & \\
\hline CED & 25 & & & & & 3 & 1 & 2 & 13 & 1 & 3 \\
\hline CEZ & 46 & & & & 9 & 16 & 7 & 6 & 5 & 3 & 2 \\
\hline $\mathrm{CTZ}$ & 25 & & & & & 16 & 7 & 2 & & 1 & \\
\hline CEC & 25 & & & & & 9 & 12 & 3 & 1 & & \\
\hline $\mathrm{CPZ}$ & 25 & 4 & 10 & 5 & 2 & 2 & 1 & 1 & & & \\
\hline СТМ & 25 & 18 & 4 & 2 & 1 & & & & & & \\
\hline LMOX & 25 & 12 & 7 & 3 & 2 & 1 & & & & & \\
\hline
\end{tabular}

Table 6 Comparison of antibacterial activity of Cefmenoxime with that other antibiotics against $P$. mirabilis

\begin{tabular}{|c|c|c|c|c|c|c|c|c|c|c|c|}
\hline \multirow{2}{*}{ Drugs } & \multirow{2}{*}{$\begin{array}{l}\text { No. of } \\
\text { strains }\end{array}$} & \multicolumn{10}{|c|}{ Minimum inhibitory concentration $(\mu \mathrm{g} / \mathrm{ml})$} \\
\hline & & $\leqq 0.2$ & 0.39 & 0.78 & 1.56 & 3.13 & 6.25 & 12.5 & 25 & 50 & $\geqq 100$ \\
\hline $\mathrm{CMX}$ & 24 & 22 & 2 & & & & & & & & \\
\hline $\mathrm{ABPC}$ & 18 & & & & 1 & 2 & 9 & 2 & 1 & & 3 \\
\hline $\mathrm{ACPC}$ & 14 & & & & & & & & & 4 & 10 \\
\hline CBPC & 27 & & & & 12 & 8 & 3 & & 4 & & \\
\hline SBPC & 26 & & & & 3 & 7 & 12 & & 4 & & \\
\hline AKM & 10 & & & & & & & & & & 10 \\
\hline RSM & 20 & & & & & 4 & 5 & 3 & 5 & 3 & \\
\hline $\mathrm{GM}$ & 22 & & & 7 & 7 & 4 & 2 & & 1 & & 1 \\
\hline LVDM & 20 & & & & & & 1 & 7 & 4 & & 8 \\
\hline CEX & 18 & & & & & & 2 & 3 & 6 & 2 & 5 \\
\hline CED & 23 & & & & & & 2 & 12 & 6 & 3 & \\
\hline CEZ & 27 & & & & & 8 & 15 & 3 & & 1 & \\
\hline CEPR & 24 & & & & & 2 & 4 & 7 & 9 & 2 & \\
\hline CTZ & 23 & & & & 1 & 12 & 6 & 2 & 1 & 1 & \\
\hline $\mathrm{CEC}$ & 24 & & & & & 2 & 4 & 11 & 6 & 1 & \\
\hline $\mathrm{CPZ}$ & 24 & & 2 & 6 & 10 & 3 & 2 & 1 & & & \\
\hline CTM & 24 & & 1 & 14 & 7 & 2 & & & & & \\
\hline LMOX & 24 & 11 & 6 & 1 & & 4 & 2 & & & & \\
\hline
\end{tabular}


Table 7 Comparison of antibacterial activity of Cefmenoxime with that of other antibiotics against K. pneumoniae

\begin{tabular}{|c|c|c|c|c|c|c|c|c|c|c|c|}
\hline \multirow{2}{*}{ Drugs } & \multirow{2}{*}{$\begin{array}{l}\text { No. of } \\
\text { strains }\end{array}$} & \multicolumn{10}{|c|}{ Minimum inhibitory concentration $(\mu \mathrm{g} / \mathrm{ml})$} \\
\hline & & $\leqq 0.2$ & 0.39 & 0.78 & 1.56 & 3.13 & 6.25 & 12.5 & 25 & 50 & $\geqq 100$ \\
\hline $\mathrm{CMX}$ & 20 & 15 & 3 & 2 & & & & & & & \\
\hline $\mathrm{ABPC}$ & 7 & & & & & 1 & & & 1 & & 5 \\
\hline $\mathrm{ACPC}$ & 7 & & & & & & & & & & 7 \\
\hline CBPC & 15 & & & & & & 1 & 1 & & & 13 \\
\hline SBPC & 16 & & & & & & 2 & & & & 14 \\
\hline AKM & 2 & & & & & & 2 & & & & \\
\hline $\mathrm{RSM}$ & 16 & & & & 1 & 8 & 3 & 2 & 1 & & 1 \\
\hline GM & 17 & 6 & & 7 & 4 & & & & & & \\
\hline LVDM & 29 & & & & 2 & 2 & 5 & 6 & & & 4 \\
\hline CEX & 8 & & & 1 & & 2 & 1 & 4 & & & \\
\hline CED & 20 & & & & & & 2 & 9 & 0 & 3 & \\
\hline CEZ & 18 & & & & 8 & 7 & 1 & 1 & 1 & & \\
\hline CEPR & 15 & & & & & 4 & 8 & & & 1 & 2 \\
\hline CTZ & 20 & & & & 10 & 7 & 2 & 1 & & & \\
\hline CEC & 20 & & & & 1 & 2 & 9 & 6 & 2 & 5 & \\
\hline $\mathrm{CPZ}$ & 20 & 3 & 7 & 5 & 2 & 1 & 1 & 1 & & & \\
\hline CTM & 20 & 11 & 5 & 3 & 1 & & & & & & \\
\hline$=\overline{\mathrm{LMOX}}$ & 20 & 9 & 6 & 3 & 2 & & & & & & \\
\hline
\end{tabular}

Table 8 Comparison of antibacterial activity of Cefmenoxime with that of other antibiotics against. P. aeruginosa

\begin{tabular}{|c|c|c|c|c|c|c|c|c|c|c|c|}
\hline \multirow{2}{*}{ Drugs } & \multirow{2}{*}{$\begin{array}{l}\text { No. of } \\
\text { strains }\end{array}$} & \multicolumn{10}{|c|}{ Minimum inhibitory concentration $(\mu \mathrm{g} / \mathrm{ml})$} \\
\hline & & $\leqq 0.2$ & 0.39 & 0.78 & 1.56 & 3.13 & 6.25 & 12.5 & 25 & 50 & $\geqq 100$ \\
\hline CMX & 60 & & & & & & 12 & 26 & 18 & 4 & \\
\hline $\mathrm{CBPC}$ & 60 & & & & & & 2 & & 3 & 21 & 34 \\
\hline SBPC & 37 & & & & & & 1 & 2 & 12 & 15 & 7 \\
\hline KSM & 60 & & & & & & & 1 & 1 & 2 & 56 \\
\hline GM & 60 & 2 & 5 & 2 & 14 & 17 & 6 & 6 & 6 & 1 & 1 \\
\hline PLB & 60 & & & 2 & 9 & 23 & 14 & 2 & & 3 & 7 \\
\hline $\mathrm{CL}$ & 60 & & & & & & 5 & 17 & 18 & 7 & 13 \\
\hline LVDM & 60 & & & & & & 2 & 1 & 8 & 17 & 32 \\
\hline $\mathrm{DKB}$ & 60 & & 8 & 12 & 22 & 8 & 10 & & & & \\
\hline TOB & 60 & & 4 & 19 & 16 & 12 & 6 & 2 & 1 & & \\
\hline AMK & 33 & & & 3 & 5 & 14 & 7 & 2 & 2 & & \\
\hline $\mathrm{CPZ}$ & 60 & & & 2 & 5 & 16 & 22 & 8 & 4 & 1 & 2 \\
\hline CFS & 60 & & & & 6 & 23 & 10 & 7 & 2 & 3 & \\
\hline LMOX & 60 & & & & & 2 & 7 & 24 & 16 & 8 & 3 \\
\hline
\end{tabular}




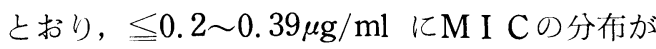
みられ，そのM I C の peak は $\leqq 0.2 \mu \mathrm{g} / \mathrm{ml}$ に認められ，他の cephalosporin 系抗生物質 を含めた比較抗生物質より Cefmenoximeの 抗菌力が上迴っていた。

病单分離の Klebsilla pneumoniae 20 株に対 する Cefmenoximeの抗菌力は, Table 7 に示

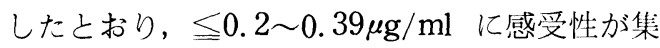
中し, $\leqq 0.2 \mu \mathrm{g} / \mathrm{ml}$ に M I C の peak がみら れ, 他の比較抗生物質より極めて強い抗菌力を
示した。

病巣分離の Pseudomonas aeruginosa 60 株 に対する Cefmenoxime の抗菌力は, Table 8 に示したとおり，6.25 $50 \mu \mathrm{g} / \mathrm{ml}$ の比較的高 いM I Cとなり, $12.5 \mu \mathrm{g} / \mathrm{ml}$ にM I Cの peak が認められた. Cefmenoxime は, 該菌に対し て aminoglycoside 系抗生物質より抗菌力は弱 かったが, その他の抗緑膿菌性抗生物質とほ之 んど同等もしくは数段階抗菌力が優っていた.

\section{Cefmenoxime の水溶液の安定性}

新抗生物質 Cefmenoxime 水溶液の安定性に ついて検討を行なった.

1 ）実験方法: Cefmenoxime 水溶液の安定 性に関しては，Cefmenoximeの標準品を滅菌 蒸留水で $20 \mathrm{mg} / \mathrm{ml}$ 含有の割合で溶解した水溶 液を $5^{\circ} \mathrm{C}$ (水庫) および $37^{\circ} \mathrm{C}$ (孵卵器) の状態 で保存し，24時間ごと 12 日間にわたり，その水 溶液の外観，色調， $\mathrm{pH}(7.2)$ および抗菌力価 の変動について調べた.

Cefmenoxime の抗菌力の測定は，前记した 日本化学療法学会M I C小委員会の指示基準に したがい寒天平板希橎法により試験菌株を Escherichia coli NIHJ JC-2 株 (Cefmenoxime の M I C 值は $0.2 \mu \mathrm{g} / \mathrm{ml}$ ) とし, Cefmenoxime 水溶液の抗菌力価（M I C ）の経時的変動を観 察した。

2 ）実験成績: Cefmenoxime $20 \mathrm{mg} / \mathrm{ml}$ 水 溶液の安定性は，前記した実験方法にしたがい 調べた結果, Cefmenoxime 水溶液は12日間に わたる $5^{\circ} \mathrm{C}$ おび $37^{\circ} \mathrm{C}$ 保存により，その水溶液 の外観，色調ならびに $\mathrm{pH}$ にほとんど変化はみ られなかった。

Cefmenoxime 水溶液の抗菌力の变動は, Fig. 2 亿示したとおり, $5^{\circ} \mathrm{C}$ 保存の場合, 6 日 まではまったく抗菌力価の低下は認められなか
ったが，8日以降は経時的にM I C 值の上昇傾 向がみられた。また， $37^{\circ} \mathrm{C}$ 保存の場合，2 日ま では抗菌力に変動がなかったが，4 日以降はM I C 值の急激な上昇がみられ始め, 抗菌力価の 低下が認められた。

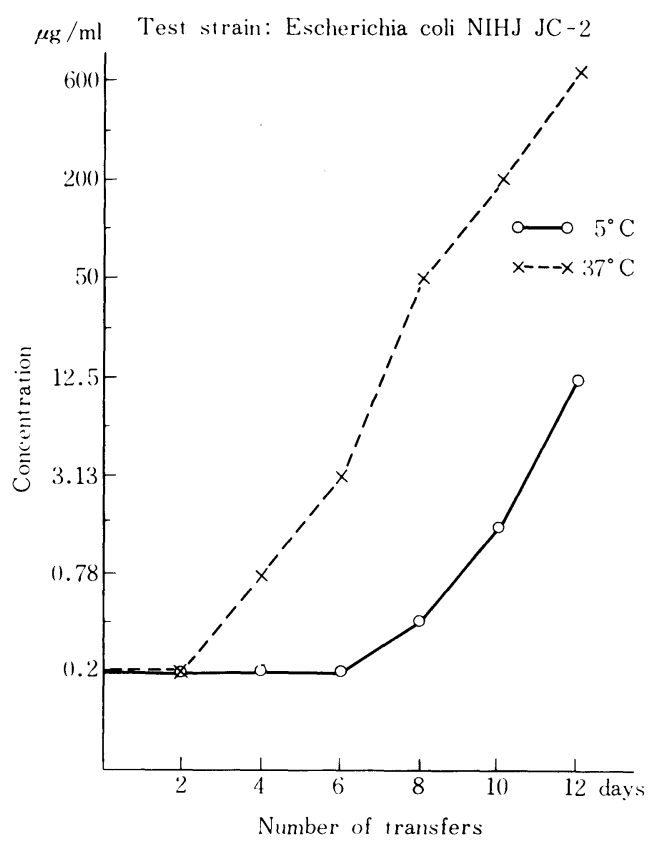

Fig. 2 Stability of Cefmenoxime solution $(20 \mathrm{mg} / \mathrm{ml}$ ) 


\section{化膿性中耳资に対する局所的応用}

新 cephalosporin 系抗生物質 Cefmenoxime を急性および慢性化膿性中耳炎に対して局所的 忘用を行ない, その臨床治療成績を検討した。

1 ）使用対象：Cefmenoxime 点耳液の使用 対象は, 最近, 札幌聥信病院耳鼻咽喉科外来を 訪れた急性化膿性中耳炎19例および慢性化膿性 中耳炎14例，総計33例（男22例，女11例）を Cefmenoxime 点耳液の使用対象とした。

なお，慢性化膿性中耳炎例では，鼓膜大穿 孔, 真珠腫形成例やX 線所見上, 中耳乳様蜂巣 に明らかに骨破壊像の認められた症例は本治療 対象加除外し, 化膿性中耳炎の保存的薬物療 法の適応症例のみに使用した。

2 ) 使用方法: Cefmenoxime 点耳液の化膿 性中耳炎に対する使用方法は, Cfmenoexime $20 \mathrm{mg} / \mathrm{ml}$ の含有割合で滅菌蒸留水で溶解調整 を行ない水庫内に保存した. 本点耳液を使用す る場合, 外耳道および鼓室内の分泌物, 痂皮な ぞを十分清拭後, 患側耳に Cefmenoxime 20 $\mathrm{mg} / \mathrm{ml}$ 点耳液を $0.5 \mathrm{ml}$ 滴下し, 約 10 分間以上 耳浴を行ない, その後外耳道内の点耳液を清拭 後, 滅菌小ガーゼ片を扦入した。 また, 急性化 膿性中耳炎の鼓膜膨隆例は, あらかじめ, 鼓膜 切開を行ない十分排膿を計り, 鼓膜の小穿孔例 では Cefmenoxime 点耳液を注射器で経鼓膜的 に鼓室内に注入を行なうか, あるいはポリッエ ル氏ゴム球で鼓室内に軽く压迫流入させて耳浴 療法を行なった。

3 ) 治療効果の判定基準 : Cefmenoxime 20 $\mathrm{mg} / \mathrm{ml}$ 点耳液による局所的応用の治療効果の 判定基準は, 急性化膿性中耳炎之慢性化膿性中 耳炎とに区別して, 自覚症状の軽快, 耳漏の消 失乾燥, 菌培養検査陰性化を主目標としたが, さらに発赤, 浮腫, 腫脹および肉芽組織増生な ぞの资症性反応の消退状態も治療効果の判定資 料とした。

Cefmenoxime 点耳液による臨床治療効果は, 一応, 便宜的に有効 Good $(H)$, やや有効 Fair
(十)および無効 Poor $(-) の 3$ 段階に区分し た。すなわち, 急性化膿性中耳炎の場合には, Cefmenoxime 点耳液による治療開始 1 週間以 内に解熱, 耳痛, 耳漏, 耳内閉塞感および難聴 などの自覚症状が軽快消失し, 菌培養陰性化が みられ, 鼓膜の発赤, 膨隆および穿孔などが消 退治癒したものを有効 $\operatorname{Good}(+)$, 同様状態が 2 週間以内に軽快消失し治癒したものをやや有 効 Fair $(+)$, それ以上本点耳液による耳浴療 法を継続しても治癒傾向の認められなかったも のを無効 Poor (ー) と判定した.

また, 慢性化膿性中耳炎の場合は, 他覚的所 見の改善を重視して Cefmenoxime 点耳液によ る治療開始後, 2 週間以内に耳漏, 耳鳴, 難㮰 などの自覚症状が軽快し, 耳漏消失, 菌培養陰 性化，鼓膜の穿孔が縮少，閉鎖し，鼓室粘膜の 浮腫, 肥厚, 肉芽組織が消退し, 耳内病変を改 善しえたものを有効 $\operatorname{Good}(H)$, 同様状態が 3 週間以内に消退改善しえたものをやや有効 Fair $(+)$ ，それ以上 Cefmenoxime 点耳液による耳 浴療法を継続しても耳内病変の改善治癒傾向の 認められなかったものを無効 $\operatorname{Pood}($ ( ) と判定 した.

なお, Cefmenoxime 点耳液使用症例の耳漏 または分泌物中から細菌の分離同定を行ない， その分離菌についてM I Cを測定し, Cefmenoxime 点耳液による治療効果を検討するさい の判定資料とした。

4 ）臨床治療成績：急性および慢性化膿性中 耳炎に対する Cefmenoxime 点耳液による局的 所応用は，前記の使用条件にしたがい臨床治療 効果を検討した結果，つぎのとおりの治療成績 がえられた。

i ）急性化膿性中耳炎：Cefmenoxime 点耳 液を本疾患19例に対して局所応用を行なった結 果, Table 9 亿示したとおり, Cefmenoxime 点耳液による耳浴は 4 ～16日間耳浴療法を行な った. Cefmenoxime 点耳液による治療成績は， 
Table 9 Therapeutic results of Cefmenoxime against acute purulent otitis media

\begin{tabular}{|c|c|c|c|c|c|c|c|c|c|c|}
\hline No. & Case & Age & Sex & Bacterial isolates & $\left|\begin{array}{c}\mathrm{MIC} \\
(\mu \mathrm{g} / \\
\mathrm{ml})\end{array}\right|$ & $\begin{array}{l}\text { Ear } \\
\text { wash } \\
\text { (day) }\end{array}$ & $\begin{array}{l}\text { Disappea- } \\
\text { rance of } \\
\text { otorrhea }\end{array}$ & $\begin{array}{l}\text { Days } \\
\text { for } \\
\text { cure }\end{array}$ & $\begin{array}{l}\text { Side } \\
\text { effect }\end{array}$ & $\begin{array}{l}\text { Effe- } \\
\mathrm{ct}\end{array}$ \\
\hline 1 & & 31 & F. & Staphylococcus aureus & 0.78 & 5 & 3 & 5 & - & H \\
\hline 2 & & 51 & M. & Staphylococcus aureus & 1.56 & 9 & 4 & 9 & - & + \\
\hline 3 & & 8 & $\mathrm{~F}$. & Staphy lococcus epidermidis & 3. 13 & 4 & 2 & 4 & - & $H$ \\
\hline 4 & & 5 & M. & Streptococcus pyogenes & $<0.1$ & 5 & 3 & 5 & - & H \\
\hline 5 & & 10 & $\mathrm{M}$. & Streptococcus pneumoniae & $<0.1$ & 5 & 2 & 5 & - & H \\
\hline 6 & & 32 & M. & Streptococcus pneumoniae & $<0.1$ & 5 & 3 & 5 & - & H \\
\hline 7 & & 7 & F. & Haemophilus influezae & $<0.1$ & 4 & 2 & 4 & - & H \\
\hline 8 & & 9 & M. & Haemophilus influenzae & $<0.1$ & 4 & 2 & 4 & - & $H$ \\
\hline 9 & & 5 & F. & Haemophilus influenzae & $<0.1$ & 6 & 3 & 6 & - & H \\
\hline 10 & & 5 & F. & $\begin{array}{l}\text { Streptococcus pyogenes } \\
\text { Haemophilus influenzae }\end{array}$ & $\begin{array}{l}<0.1 \\
<0.1\end{array}$ & 5 & 2 & 5 & - & H \\
\hline 11 & & 5 & $\mathrm{M}$. & Serratia marcescens & 1.56 & 7 & 4 & 7 & - & tt \\
\hline 12 & & 44 & M. & Corynebacterium & & 6 & 3 & 6 & - & $H$ \\
\hline 13 & & 33 & E. & no growth & & 5 & 2 & 5 & - & H \\
\hline 14 & & 6 & $\mathrm{M}$. & no growth & & 5 & 3 & 5 & - & H \\
\hline 15 & & 38 & M. & no growth & & 16 & $?$ & $?$ & - & - \\
\hline 16 & & 5 & $\mathrm{M}$. & no growth & & 5 & 3 & 5 & - & H \\
\hline 17 & & 24 & M. & no growth & & 6 & 3 & 6 & - & H \\
\hline 18 & & 8 & F. & no growth & & 5 & 3 & 5 & - & H \\
\hline 19 & & 10 & M. & no growth & & 4 & 2 & 4 & - & H \\
\hline
\end{tabular}

平均 3 日間で耳痛軽快, 耳漏, 耳内閉塞感, 鼓 膜膨隆などの主要症状が消失し，菌培養が陰性: 化した，有効症例は，本点耳液使用平均 5 日で 自覚症状がまったく軽快, 外耳道内は乾燥し, 鼓膜の穿孔は閉鎖，発赤が消退して治癒した。

本症の耳漏分離菌は, 単独感染が Staphylococcus aureus (MIC: $0.78 \sim 1.56 \mu \mathrm{g} / \mathrm{ml}$ ) 2 株, Staphylococcus epidermidis (MIC : 3.13 $\mu \mathrm{g} / \mathrm{ml}$ ) 1 株, Streptococcus pyogenes(MIC : $<0.1 \mu \mathrm{g} / \mathrm{ml}) 1$ 株, Streptococcus pneumoniae (MIC : $<0.1 \mu \mathrm{g} / \mathrm{ml}) 2$ 株, Haemophilus influenzae (MIC : $<0.1 \mu \mathrm{g} / \mathrm{ml}$ ) 3 株, Serratia marcescens (MIC $: 1.56 \mu \mathrm{g} / \mathrm{ml}$ ), Corynebacterium 1 株および混合感染は Streptococcus pyogenes (MIC : $<0.1 \mu \mathrm{g} / \mathrm{ml}$ ) + Haemophilus influenzae (MIC: $<0.1 \mu \mathrm{g} / \mathrm{ml}) 2$ 例と培養で 菌の発育しなかったものが 7 例認められた。

Cefmenoxime $20 \mathrm{mg} / \mathrm{ml}$ 点耳液による急性化
膿性中耳炎19例に対する臨床治療効果は,

Table 11 に示したとおり, 有効17例, やや有 効 1 例㧍よび無効 1 例となり，その有効率は有 効，やや有効例を合算すると 18 例 $94.7 \%$ となっ た。 また，急性化膿性中耳炎に対する Cefmenoxime の分離菌別治療効果は, Table 11 に 示したとおり, Staphylococcus aureus, Streptococcus pyogenes, Streptococcus pneumoiae および Haemophilus influenzae など の分離症例に有効例がみられた。

本点耳液使用中，とくに臨床的に副作用之考 えられる症状の発現はまったく認められなかっ た。

ii ）慢性化膿性中耳炎：Cefmenoxime 点耳 液を本疾患14症に対して局所的に使用した結 果, Table 10 に示したとおり, Cefmenoxime 点耳耳浴は有効例で平均 6 日間で耳漏, 耳内閉 塞感, 難㭡などの自覚症状は軽快し, 外耳道お 
Table 10 Therapeutic results of Cefmenoxime against chronic purulent otitis media

\begin{tabular}{|c|c|c|c|c|c|c|c|c|c|c|}
\hline No. & Case & Age & Sex & Bacterial isolates & 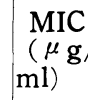 & $\begin{array}{l}\text { Ear } \\
\text { wash } \\
\text { (day) }\end{array}$ & $\begin{array}{l}\text { Disappea- } \\
\text { rance of } \\
\text { otorrhea }\end{array}$ & $\begin{array}{l}\text { Days } \\
\text { for } \\
\text { cure }\end{array}$ & $\begin{array}{l}\text { Side } \\
\text { effect }\end{array}$ & $\underset{c t}{E f f e-}$ \\
\hline 1 & & 33 & M. & Staphylococcus aureus & 0.39 & 6 & 4 & 6 & - & H \\
\hline 2 & & 35 & M. & Staphylococcus aureus & 3.13 & 22 & $?$ & $?$ & - & - \\
\hline 3 & & 47 & M. & Staphylococcus aureus & 0.78 & 10 & 5 & 10 & - & H \\
\hline 4 & & 49 & F. & Staphylococcus epidermidis $(R)$ & 0.78 & 8 & 4 & 8 & - & H \\
\hline 5 & & 49 & F. & Staphylococcus epidermidis $(\mathrm{L})$ & 1.56 & 16 & 8 & 16 & - & + \\
\hline 6 & & 59 & M. & $\begin{array}{l}\text { Staphylococcus epidermidis } \\
\text { Corynebacterium }\end{array}$ & 3.13 & 22 & ? & ? & - & - \\
\hline 7 & & 46 & F. & Proteus mirabilis & 0.2 & 10 & 6 & 10 & - & H \\
\hline 8 & & 53 & M. & Pseudomonas aeruginosa & 6.25 & 15 & 6 & 15 & - & + \\
\hline 9 & & 64 & M. & Pseudomonas aeruginosa & 12.5 & 16 & 7 & 16 & - & + \\
\hline 10 & & 52 & M. & $\begin{array}{l}\text { Pseudomonas aeruginosa }(R) \\
\text { Klebsiella pneumoniae }\end{array}$ & $\begin{array}{l}6.25 \\
0.39\end{array}$ & 15 & 6 & 15 & - & + \\
\hline 11 & & 52 & M. & $\begin{array}{l}\text { Staphylococcus epidermidis } \\
\text { Corynebacterium (L) }\end{array}$ & 3.13 & 22 & $?$ & ? & - & - \\
\hline 12 & & 50 & M. & $\begin{array}{l}\text { Pseudomonas aeruginosa } \\
\text { Serratia marcescens }\end{array}$ & $\begin{array}{l}50 \\
3.13\end{array}$ & 22 & $?$ & $?$ & - & - \\
\hline 13 & & 37 & F. & $\begin{array}{l}\text { Providencia } \\
\text { Corynebactrium }\end{array}$ & & 11 & 6 & 11 & - & H \\
\hline 14 & & 54 & M. & $\begin{array}{l}\text { Proteus mirabilis } \\
\text { Corynebacterium }\end{array}$ & 0.2 & 22 & $?$ & $?$ & - & - \\
\hline
\end{tabular}

Table 11 Efficacy of Cefmenoxime by species of disease

\begin{tabular}{c|c|c|c|c}
\hline \hline Efficacy & Good(+t) & Fair(+) & Poor(-) & Total \\
\hline Diagnosis & 17 & 1 & 1 & 19 \\
Acute purulent otitis media & 5 & 4 & 5 & 14 \\
\hline Thronic purulent otitis media & 22 & 5 & 6 & 33 cases
\end{tabular}

よび鼓室内の分泌物が消失乾燥し，菌培養が除 性化した。本点耳液使用平均13日間で自覚症状 は軽快，外耳道および鼓室内の膿汁または分泌 物が消失乾燥し，鼓膜穿孔は閉鎖，鼓室粘膜の 浮腫，肥厚，肉芽組織増生などは消退して耳内 所見を改善させえた.

本症の耳漏からの分離菌は, 単独感染で Staphylococcus aureus (MIC:0.39 3.13 $\mu \mathrm{g}$ / ml) 3 株, Staphylococcus epidermidis (MI $\mathrm{C}: 0.78 \sim 1.56 \mu \mathrm{g} / \mathrm{ml}) 2$ 株, Proteus mirabilis (MIC $: 0.2 \mu \mathrm{g} / \mathrm{ml}$ ) 1 株, Pseudomonas aeruginosa (MIC : $6.25 \sim 12.5 \mu \mathrm{g} / \mathrm{ml}$ ) 1 株を 検出した, また, 混合感染では, Staphlococcus epidermidis (MIC : $3.13 \mu \mathrm{g} / \mathrm{ml}$ ) + Corynebacterium 2 例, Pseudomonas aeruginosa (M IC $: 6.25 \mu \mathrm{g} / \mathrm{ml})+$ Klebsiella pneumoniae $(M$ 
Table 12 Clinical response of Cefmenoxime classified of clinical isolates against acute purulent otitis media

\begin{tabular}{l|c|c|c|c}
\hline \hline \multicolumn{1}{c|}{ Efficacy } & Good (+t) & Fair $(+)$ & Poor $(-)$ & Total \\
\hline Clinica lisolates & 1 & 1 & & 2 \\
Staphylococcus aureus & 1 & & & 1 \\
Staphylococcus epidermidis & 1 & & & 1 \\
Streptococcus pyogenes & 1 & & & 1 \\
Streptococcus pyogenes & 2 & & & 2 \\
Haemophilus influenzae & 3 & & & 3 \\
Streptococcus pneumoniae & 1 & & & 1 \\
Haemophilus influenzae & 1 & & & 7 \\
Serratia marcescens & 6 & & 1 & 19 cases \\
Corynebacterium & 17 & 1 & 1 &
\end{tabular}

Table 13 Clinical response of Cefmenoxime classified of clinical isolates against chronic purulent otitis media

\begin{tabular}{|c|c|c|c|c|}
\hline Clinical isolates $\quad$ Efficacy & Good (H) & Fair $(+)$ & Poor $(-)$ & Total \\
\hline Staphylococcus aureus & 2 & \multirow{3}{*}{1} & 1 & 3 \\
\hline Staphylococcus epidermidis & 1 & & & 2 \\
\hline $\begin{array}{l}\text { Staphylococcus epidermidis } \\
\text { Corynebacterium }\end{array}$ & & & 2 & 2 \\
\hline Proteus mirabilis & 1 & \multirow{6}{*}{$\begin{array}{l}2 \\
1\end{array}$} & & 1 \\
\hline $\begin{array}{l}\text { Proteus mirabilis } \\
\text { Corynebacterium }\end{array}$ & & & 1 & 1 \\
\hline Pseudomonas aeruginosa & & & & \\
\hline $\begin{array}{l}\text { Pseudomonas aeruginosa } \\
\text { Klebsiella pneumoniae }\end{array}$ & & & & $\begin{array}{l}2 \\
1\end{array}$ \\
\hline $\begin{array}{l}\text { Pseudomonas aeruginisa } \\
\text { Serratia marcescens }\end{array}$ & & & & 1 \\
\hline $\begin{array}{l}\text { Providencia } \\
\text { Corynbacterium }\end{array}$ & 1 & & & 1 \\
\hline Total & 5 & 4 & 5 & 14 cases \\
\hline
\end{tabular}

IC $: 0.39 \mu \mathrm{g} / \mathrm{ml}) \quad 1$ 例, Pseudomonas aeruginosa $(\mathrm{MIC}: 50 \mu \mathrm{g} / \mathrm{ml})+$ Serratia marcescens (MIC $: 3.13 \mu \mathrm{g} / \mathrm{ml}) \quad 1$ 例, Providencia + Corynebactium 1 例, Proteus mirabilis (MI $\mathrm{C}: 0.2 \mu \mathrm{g} / \mathrm{ml})+$ Corynebacterium 1 例を分 離した.

Cefmenoxime 点耳液による本症の臨床治療
効果は, Table 11 に示したとおり, 有効 5 例, やや有効 4 例および無効 5 例となり，その有効 率は有効，やや有効例を合算すると 9 例 $64.3 \%$ となった。

本症に対する Cefmenoxime 点耳液の分離 菌別治療効果は，Table12，13 に示したとお り, Staphylococcus aureus, Staphylococcus 
Table 14 Interrelation between MIC and clinical response of Cefmenoxime on the acute purulent otitis media

\begin{tabular}{|c|c|c|c|c|c|c|c|c|c|c|c|}
\hline \multirow{2}{*}{\multicolumn{2}{|c|}{ Efficacy }} & \multicolumn{10}{|c|}{ Minimum inhibitory concentration $(\mu \mathrm{g} / \mathrm{ml})$} \\
\hline & & $\leqq 0.2$ & 0.39 & 0.78 & 1.56 & 3.13 & 6.25 & 12.5 & 25 & 50 & $\geqq 100$ \\
\hline \multirow{4}{*}{ 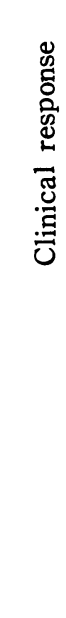 } & $\begin{array}{c}\text { Good } \\
(+t)\end{array}$ & $\begin{array}{l}\times \square \triangle \\
\times \square \triangle \\
\triangle \\
\triangle\end{array}$ & & O & $\oplus$ & ○ & & & & & \\
\hline & $\begin{array}{l}\text { Fair } \\
(+)\end{array}$ & & & & 0 & & & & & & \\
\hline & $\begin{array}{c}\text { Poor } \\
(-)\end{array}$ & & & & & & & & & & \\
\hline & \multicolumn{5}{|c|}{$\begin{array}{l}\text { * OStaphylococcus aureus } 2 \text { strains } \\
\times \text { Streptococcus pyogenes } 2 \text { strains } \\
\triangle \text { Haemophilus influenzae } 4 \text { strains }\end{array}$} & \multicolumn{6}{|c|}{$\begin{array}{l}\text { OStaphylococcus epidermidis } 1 \text { strain } \\
\square \text { Streptococcus pneumoniae } 2 \text { strains } \\
\oplus \text { Serratia marcescens } 1 \text { strain }\end{array}$} \\
\hline
\end{tabular}

Table 15 Interrelation between MIC of clinical isolates and clinical response of Cefmenoxime on the chronic purulent otitis media

\begin{tabular}{|c|c|c|c|c|c|c|c|c|c|c|c|}
\hline \multirow{2}{*}{\multicolumn{2}{|c|}{ MIC }} & \multicolumn{10}{|c|}{ Minimum inhibitory concentration $(\mu \mathrm{g} / \mathrm{ml})$} \\
\hline & & $\leqq 0.2$ & 0.39 & 0.78 & 1.56 & 3.13 & 6.25 & 12.5 & 25 & 50 & $\geqq 100$ \\
\hline \multirow{4}{*}{ 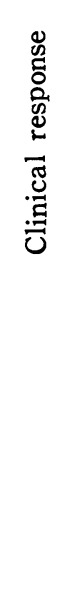 } & $\begin{array}{c}\text { Good } \\
(+H)\end{array}$ & $\bigotimes$ & O & $\bigcirc$ & & & & & & & \\
\hline & $\begin{array}{l}\text { Fair } \\
(+)\end{array}$ & & (2) & & - & & $\hat{\Delta}$ & $\boldsymbol{\Delta}$ & & & \\
\hline & $\begin{array}{c}\text { Poor } \\
(-)\end{array}$ & 区 & & & & ○९ & & & & $\Delta$ & \\
\hline & $\begin{array}{l}\text { * OStapl } \\
\text { 叉Prote } \\
\oplus \text { Serra }\end{array}$ & $\begin{array}{l}\text { ococcus } \\
\text { mirab } \\
\text { marce }\end{array}$ & $\begin{array}{l}\text { aureus } \\
\text { is } 2 \text { st } \\
\text { cens } 1\end{array}$ & $\begin{array}{l}\text { strai } \\
\text { ins } \\
\text { trin }\end{array}$ & & $\begin{array}{l}\text { OSt } \\
\Delta \mathrm{Ps} \\
\mathrm{OKl}\end{array}$ & $\begin{array}{l}\text { hyloc } \\
\text { udomn } \\
\text { bsiella }\end{array}$ & $\begin{array}{l}\text { us epi } \\
\text { aerugi } \\
\text { neumor }\end{array}$ & 1 st & $\begin{array}{l}\text { strai } \\
\text { ns } \\
\text { n }\end{array}$ & \\
\hline
\end{tabular}


epidermidis, Proteus mirabilis および Pseudomonas aeruginosa などの分離症例に有効例 が認められた。

本点耳液使用中，とくに臨床的に副作用之考 えられる症状の発現はみられなかった。

急性および, 慢性化膿性中耳炎33例に対する Cefmenoxime 点耳液による臨床治療効果は,
Table 11 に示した之おり, 有効22例, やや有 効 5 例および無効 6 例となり, Cefmenoxime 点耳液の有効率は27例 $81.8 \%$ となった。

Cefmenoxime 点耳液による臨床治療効果と 耳漏分離のM I C 值とは, Table14, 15 亿示 したとおり，両者間におおむね相関関係が認め られた。

\section{総括ならびに考按}

化膿性中耳炎に対する化学療法は, 中耳腔感 染の病原菌を撲滅除菌し，外耳道および鼓室内 の分泌物を消失乾燥させ, さらに発赤, 膨隆, 穿孔および肉芽組織増生などの炎症性反応を二 次的に抑制消退させて治癒に棌くことが主目的 である。

最近, 各種の抗菌性物質, とりわけ penicillin, cephem 系などの $\beta$-lactam 系, aminoglycoside 系抗生物質および合成抗菌剂など の研究開発などが著しく，全身的投与によりか なり中耳骨, 粘膜や分泌物中に乙れら活性型物 質の移行が可能であり，高い抗菌治療効果をあ げうるようになってきだ'4)．急性および慢性． 化膿性中耳炎に対する化学療法は, 病態的に多 少相異するが，いずれにしても十分な排膿方法 を構じ，耳内局所にすぐれた適合抗菌性物質の 投与のみで所期の除菌, 耳漏乾燥の目的を達す る場合が多い。

しかし，急性および慢性化膿性中耳炎は，日 常の耳鼻咽喉科診療のさい，極好て多い疾患に 屯かかわらず最も重要な局所化学療法に使用す る点耳液が，十数年米まったく開発されないま ま，それぞれ独自の方法で点耳液を調整使用 しているのが現状である。新 Cephem 系抗生 物質 Cefmenoxime の体内動態に関して, 本剂 $500 \mathrm{mg}$ 静注後の血中濃度は, 自験例によると 薄層カップ法で15分後に $31.7 \mu \mathrm{g} / \mathrm{ml}$ と最高值 に達し， 30 分後には $18.9 \mu \mathrm{g} / \mathrm{ml}$ と減少傾向が みられ，静注 6 時間後には $0.14 \mu \mathrm{g} / \mathrm{ml}$ の血中 活性值を測定している ${ }^{2)}$. Cefmenoxime の臓 器組織内濃度は, 動物実験では腎が最む高く,
ついで肝, 肺, 脾の順で移行するといわれ ${ }^{11}$, $500 \mathrm{mg}$ 静注 1 時間後に手術時に摘出したヒト 口蓋扁桃（4 例）に $1.9 \mu \mathrm{g} / \mathrm{g}$ （血中濃度 7.7 $\mu \mathrm{g} / \mathrm{ml}$ ) と上枵洞粘膜（6 例）に $1.5 \mu \mathrm{g} / \mathrm{g}$ (血 中濃度 $7.6 \mu \mathrm{g} / \mathrm{ml}$ ) の良好な組織内活性值がえ られた ${ }^{2)}$.

Cefmenoxime の試管内抗菌力については, 寒天平板希釈法で, 標準菌株の Staphylococcus aureus は従来の cephalosporin 系注射 剂の抗菌力と同等もしくはやや少っており, Streptococcus pyogenes, Streptococcus pneumoniae に対しては $<0.1 \mu \mathrm{g} / \mathrm{ml}$ と強い抗 菌力を有していた. また, Cefmenoxlme の抗 菌力は, Escherichia coli, Proteus s.p., Klebsiella pneumoniae, Haemophilus influenzae, Serratia marcescens および Bacteroides fragilis などにも抗菌スペクトルを拡大している のが注目される。

なお, Cefmenoxime は， $\beta$-lactamase に対 しても安定性が高く，既存 cephalosporin 耐 性菌にも強い抗菌力を発揮しえるといわれてい $ろ^{11}$.

化膿性中耳炎の耳漏分離 coagulase 陽性ブ ドウ球菌80株に対する Cefmenoxime は，0.39 $\sim 6.25 \mu \mathrm{g} / \mathrm{ml}$ の範囲内に感受性が分布し, 1.5 $\mu \mathrm{g} / \mathrm{ml}$ にM I Cの peak がみられ, 従来の cephalosporin 系注射剂よりグラム陽性菌にはや や抗菌力は弱かったが, $12.5 \mu \mathrm{g} / \mathrm{ml}$ 以上の高 度耐性株はまったく認められなかったてとは注 目に值する。

病巣分離の Escherichia coli 25株, Proteus 
mirabilis 24株および Klebsiella pneumoniae 20 株には， $\leqq 0.2 \sim 0.78 \mu \mathrm{g} / \mathrm{ml}$ の範囲内にM I Cが分布し，そのM I Cの peak はいずれもミ $0.2 \mu \mathrm{g} / \mathrm{ml}$ と低く, 該菌に対する抗菌力の著し く強いことは Cefmenoximeの大きな特徵とい える。

Cefmenoxime 製剂の安定性については, 窣 温で 2 年以上安定であるとされ，本剂を蒸留水 やカルボカイン水溶液に溶解した場合, $25^{\circ} \mathrm{C}$, 24時間後でも $90 \%$ 以の残存率を示しており, $5 \%$ グルース $500 \mathrm{ml}$ や生理食塩水 $500 \mathrm{ml}$ 中 ではさらに安定であり， $25^{\circ} \mathrm{C} 24$ 時間後でも $95 \%$ 以上の残存率を示すという ${ }^{1)}$. Cefmenoxine 20 $\mathrm{mg} / \mathrm{ml}$ 水溶液の $5^{\circ} \mathrm{C}$ 保存の場合, 6 日間抗菌 力価の低下がみられなかったが, $37^{\circ} \mathrm{C}$ 保存の場 合, 2 日間で抗菌力価が著しく低下し始め, 他 のCephalosporin 系抗生物質同様にできうる 限り, 点耳液として局所的応用するさいは用時 溶解するのが便宜的といえよう.

Cefmenoxime 20mg 点耳液を急性および慢 性化膿性中耳炎に点耳液として局所応用した結 果, 急性化膿性中耳炎の場合, 平均耳浴 3 日間 で耳痛, 耳閉塞感, 鼓膜膨隆, 耳漏が軽快消 失し, 5 日間で自覚症状が軽快, 鼓膜の穿孔, 発赤は短時日で消退し治癒する傾向が認められ た。なお, 耳漏分離菌は, Staphylococcus aureus, Streptococcus pyogenes および Streptococcus pneumoniae などのグラム陽性菌 が大部分であり，そのM I Cは<0.1〜3.13 $\mu \mathrm{g} /$ $\mathrm{ml}$ の低濃度で菌の発育を阻止しえたことは有

\section{結}

新 Cephem 系抗生物質 Cefmenoxime に関 して, その試験管内抗菌力, 水溶液の安定性の 検討および化膿性中耳炎に対して局所的に応用 した結果，つぎのとおり結論がえられた。

1 ) 試験管内抗菌力: Cefmenoxime の試験 管内抗菌力は, 寒天平板希釈法で各標準菌株に 対してグラム陽性, 陰性菌に強い抗菌力を示し broad spectrum であった. 化膿性中耳炎の耳
効例を多くしたものと思われる, Cefmenoxime 点耳液の臨床治療効果之耳漏分離菌のM I C 值 とは, 両者および相関関係が認められ合致して おり，本点耳液の有用性を証左:できたものと思 われる.

慢性化膿性中耳炎の場合, 有効例では Cefmenoxime 点耳液で平均 6 日で耳漏, 耳内閉塞 感, 難聴などの主要症状が軽快消失し, 耳浴13 日で外耳道および鼓室内は乾燥し, 菌培養が陰 性となり, 鼓膜穿孔は閉鎖, 鼓室粘膜の浮腫, 肥厚, 肉芽組織などが消退して耳内を改善しえ たととは有用性の高い治療薬剂といえる.

なお，耳漏分離菌は，Staphylococcus aureus および Staphylococcus epidermidis (MIC: $0.39 \sim 3.13 \mu \mathrm{g} / \mathrm{ml}$ ) などのグラム陽性球菌や Proteus mirabilis (MIC: $0.2 \mu \mathrm{g} / \mathrm{ml}$ ) や Pseudomonas aeruginosa (MIC : $6.25 \sim 12.5 \mu \mathrm{g}$ / $\mathrm{ml}$ ) などのグラム陰性桿菌などの分離症例に 有効例が認められたととは高く評価されよう.

Cefmenoxime 点耳液の臨床治療効果と耳漏分 離菌のM I C值とは, 両者おおむね相関関係が みられ合致しており，本剤の有効性を評価する 裏付けとなっていた。

Cefmenoxime 点耳液による副作用は, 今回 の治療33例のうち，とくに臨床的に副作用と考 えられる症状の発現はまったく認められなかっ たが，本剂が $\beta$-lactam 系抗生物質である関係 上, アレルギー症状の発生も懸念されるあので 十分注意して使用すべきであろう.

\section{論}

漏分離 coagulase 陽性ブドウ球菌80株では, $0.39 \sim 6.25 \mu \mathrm{g} / \mathrm{ml}$ の範囲内に感受性が分布し, そのM I C の peak は $1.56 \mu \mathrm{g} / \mathrm{ml}$ に認められ た. 病巣分離の Escherichia coli, Proteus mirabilis および Klebsiella pneumoniae など は $\leqq 0.2 \sim 0.78 \mu \mathrm{g} / \mathrm{ml}$ に分布し，いずれも $\leqq$ $0.2 \mu \mathrm{g} / \mathrm{ml}$ にM I Cの peak が認められた。ま た, Pseudomonas aeruginosa は, 6.25〜50 
$\mu \mathrm{g} / \mathrm{ml}$ に分布し, $12.5 \mu \mathrm{g} / \mathrm{ml}$ にM I C の peak がみられた。

2 ）水溶液の安定性: Cefmenoxime $20 \mathrm{mg} /$ $\mathrm{ml}$ 水溶液の安.定性は, $5^{\circ} \mathrm{C}, 37^{\circ} \mathrm{C}$ で 12 日間保 存により色調, $\mathrm{pH}$ に変化なく, その抗菌力価

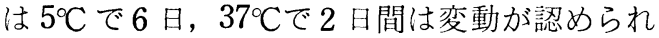
なかった。

3 ）局所使用成績: Cefmenoxime $20 \mathrm{mg} /$ $\mathrm{ml}$ 点耳液を急性および慢性化膿性中耳炎33例 に対して 4〜22日間にわたり点耳耳浴療法を行 なった結果, 有効 22 例, やや有効 5 例および無 効 6 例之なり, その有効率は有効, やや有効例 を合算すると27例 $81.8 \%$ の好成績がえられた。

なお，本点耳液使用中に臨床的に副作用之思 われる症状の発現はまったく認められなかっ た。

\section{参考 文 献}

1) 第27回日本化学療法学会総会. 新薬シンポジウ $\mathrm{T}-1551$ (1979)

2) 岩沢武彦：耳鼻咽喉科領域における T-1551 に 関する基礎的ならびに臨床的研究 Chemotherapy $28: \mathrm{S}-6,859 \sim 869,1980$.

3 ) 岩沢武彦: 新 aminoglycoside 系抗生物質 $\mathrm{KW}$ -1062（Sagamicin） の試験管内抗菌力と化膿性 中耳炎に対する局所的応用に関する検討. 耳鼻咽 喉科展望 $22 ： \mathrm{~S}-3,1 \sim 14,1979$.

4 ) 岩沢武彦：新 Cephalosprin 系抗生物質 Cefoperazone の試験管内抗菌力, 水溶液 の安定性お よび化膿性中耳炎に対する局所的応用に関する検 討. 耳鼻臨床 73：9，1481～1495, 1980 .

原稿到着：昭和57年 5 月 24 日 急載 別刷請求先 : 岩沢武彦 